\title{
Creative Accounting and Income Tax Yield: A Dependency Inquisition
}

\author{
Stanley OGOUN $\mathrm{PhD}^{1} \quad$ Emmanuel ATAGBORO ${ }^{2}$ \\ 1.Senior Lecturer, Department of Accountancy, Management Sciences, \\ Niger Delta University, Amassoma, Bayelsa State \\ 2.Department of Accountancy, Management Sciences, \\ Niger Delta University, Amassoma, Bayelsa State
}

\begin{abstract}
Quite a number of empirical evidences have shown that creative accounting practices are prevalent among Nigerian firms and management and accountants being the sole influencers of such accounting practices. More worrisome is the fact that there is dearth of empirical evidence on the nexus between creative accounting and income tax yield. Thus, this study was carried out with the view to investigating the nexus between creative accounting practices and income tax yield in Nigeria. The descriptive survey design was adopted and questionnaire was the major instrument of data collection. Questionnaire was administered to two hundred and fifty-eight (258) employees of South-South States' Boards of Internal Revenue. Data obtained were analyzed by means of descriptive (frequency counts, mean and standard deviation) and inferential (simple regression) statistical techniques. Based on the analysis of data, it was found that income tax yield is significantly affected by creative accounting practices of Nigerian firms. On the basis of the findings, it was recommended among others that the government, regulatory framework of accounting as well as management of firms should further discourage the use of creative accounting mechanisms in tweaking income tax yield. More so, the regulatory framework of accounting should as a matter of fact postulate and revise accounting standards linked with income tax yield so as to further discourage creative accounting practices among Nigerian firms.
\end{abstract}

Keywords: Creative accounting; income tax yield; federation accounts committee; Nigeria

DOI: $10.7176 / \mathrm{EJBM} / 11-33-07$

Publication date: November $30^{\text {th }} 2019$

\section{Introduction}

The Nigerian nation is structured along state lines with concentration of ownership rights of core revenue yielding assets at the center. Arising from this development, the bulk of revenue yielding assets are concentrated at the center, with the resultant national policy thrust of the Federation Accounts Committee with its acronym, FAC in the Nigerian state. This policy thrust is anchored on appropriating all critical revenues from the entire federation into a common pool at the center and distributed monthly on certain predetermined criteria. The extant literature on the Nigerian political economy has documented the evolutionary path of this current policy thrust. A review of this literature clearly demonstrates how military incursion into governance and the subsequent suspension of the constitution propelled this paradoxical federal contrition of the Nigerian State.

Exploring Nigeria's economic historical path, clearly documents the strengthening of the foregoing national policy thrust on the basis of the boom in the international market for crude oil, to which the Nigerian nation was a major beneficiary. This led to the outright methodological confinement to the background of taxation which was and is still the traditionally defined means of raising public funds (Stanley, 2016). Thus, the instrument of taxation was abandoned for the more and easier lucrative sale of crude oil at the international market for raising public funds for the nation.

However, the inflow of the massive revenue from crude oil sales began to decline occasioned by the stochastic nature of the international oil market. The glut in the international oil market which precipitated a massive decline in public revenue to the federation account triggered a massive deficit in public expenditure, payment defaults and a near total collapse of the national economy, with the resultant introduction of the International Monetary Fund (IMF) policy of Structural Adjustment Programme (SAP) in the early eighties. The steady decline in cash inflows from sale of crude oil impacted so negatively on the Nigerian economy, such that it became inevitable for the administrators of the national economy to begin to rebuild the collapsed and abandoned time tested institutional framework for generating public revenue (Stanley, 2016).

The immediate outcome of this development was the institution of a regime of massive multiple taxation with severe consequences for doing business. The initial uncoordinated efforts led to a jungle of multiple taxation and its attendant implications for doing business in the country. In response to this development the Joint Tax Board (JTB) was initiated to, not only streamline and harmonized the various tax regimes, but also to define a clear road map for deploying taxation as tool for generating public revenue. This effort led to a unification of the hitherto multiple tax regimes across the nation through categorization of jurisdictions for the harmonized tax regime amongst the various tiers of government. Also tax reforms were initiated with the enactment of the various enabling 
legislation (i.e. the Value Added Tax (VAT), Personal Income Tax Amendment Act of 2014, etc.). However, this effort did not automatically translate to a massive increase in public revenue, thus raising concerns about the existence of several leakages within the tax framework.

Given the shortfall in the anticipated tax yield, various reasons were adduced for this negative development. Principal amongst this is the corruption pandemic which has been in the front burner. However, an uncanny loophole which has been recognized in the extant literature (Graham \& Allen, 2006; Chen, 2008; Riedl \& Suraj, 2010; Tokuga \& Saki, 2011; Hossein, Sina \& Seyed 2013) as affecting income tax yield in other climes, that have consistently deployed taxation as the primary means of generating public revenue, is creative accounting. Though, the terminology is new but the practice predates its official recognition in the literature of taxation.

In this regard, it is important to reiterate the fact that taxation (whether corporate or personal) is premised on accounting numbers. These numbers especially at the corporate level are a product of accounting policies. Very emphatically, all income tax yields are a bye-product of reported accounting numbers, thus absolutely dependent on reported income, which is to some extent contingent on the accounting policies deployed. Accordingly, interrogating the implications of accounting policies on tax yield deserves the current research effort as accounting numbers manipulation or fraudulent financial reporting is well documented in the literature. A further justification for this study is anchored on the principle of replication in research, against the background that researches in this domain have been anchored in other climes. The dearth of local empirical studies to support the deposition of Ahmed and Scott, (2011), who opined that when firms engage in creative accounting, income tax yield is negatively affected.

Furthermore, earnings management or creative accounting has attracted serious debate in the academic literature. However, there is no consensus as to whether it is fraudulent or not. Both sides of the argument have proponents, thus necessitating continuous research. It is therefore not out of place to anchor the prime essence of this study on interrogating the impact of the creative accounting constructs on income tax yield in the South-South states of Nigeria.

\section{THE LITERATURE}

\subsubsection{The Creative Accounting Construct and Its Rationale}

Creative accounting or income smoothing is the utilization of accounting discretion to reduce income stream variability (Ahmed \& Scott, 2011). Smoothing moderates year-to-year fluctuations in income by shifting earnings from peak years to less successful ones, making earnings fluctuations less volatile (Moradi, 2008). As a simple definition, income smoothening is a kind of intentional act committed by managers using special tools in accountancy for lowering profit fluctuations. Through creative accounting managers are able to influence stock return and achieve goals such as job security, reward, and wealth increase of stockholders. Low profit fluctuations create a more favourable sensation in investors for investing in companies (Davoud \& Bita, 2010). Management of some companies deliberately manipulates items of financial statements in order to attract attention of investors and to mislead them towards presenting a picture of stable profitability.

Creative accounting is an accounting technique to reduce variability at the discretion of the direction of which the profits will be used. In other words, creative accounting is often used to smooth fluctuations from year to year adjusted earnings. Chen (2008) suggests three main reasons why managers smooth their earnings: first, to reach the benchmark level that has been established in the stock market, usually by analysts' forecasts; second, to meet their own performance target; and third to avoid violations of debt contracts. However, different definitions have been proffered for income smoothening, resulting in the absence of a one definition fits all scenario of the construct. However, this lack of commonality in definition has not obscured the meaning of the construct.

There is a general consensus with respect to the meaning of the construct despite the variety of definitional approaches. For instance, Atwood and Hong (2011) stated that income smoothing means lowering income fluctuation deliberately according to accounting principles so that it looks usual for companies. On their part, Tokuga and Saki (2011) state that income smoothening is an attempt exerted by management to reduce unusual changes in income, and it is defined by accounting principles. Both definitions emphasize income manipulation so that unusual returns are reduced and influence reported income towards meeting the expected threshold. On the other hand, various categories of income smoothening methods have been deployed in various instances. Siti, Haron \& Henny (2013) and Uma and Gregory (2012) categorized income smoothening into two typologies. These are the natural and the artificial smoothening.

Creative accounting is thus a financial strategy or device that accountants or organizations utilize in order to smooth income. The extant literature recognizes that income smoothening can be categorized into the positive and negative domains. Within this framework, positive income smoothening is considered ethical, while negative income smoothing is domain the realm of the unethical. Positive income smoothening is all about utilizing loopholes in accounting standards to portray a better picture of the financial performance of the organization such as written-off of Research and Development (R\&D) expenditure. This is acceptable within the financial reporting standards framework. While negative income smoothening is utilizing loopholes in accounting standards to falsify 
the financial statements that does not show the true picture of the organization.

Creative accounting or income smoothening has long been discussed as a management tactic. Here, income smoothening refers to "The equalization of income in each period to a certain level" (Al-Qaisi, 2011). That is to say, it is behaviour directed towards curbing fluctuations in income and cause income to approach the level where management's utility is maximized (Hossein, Sina, \& Seyed, 2013). More specifically, management reduces income in periods when business performance is favourable and income is comparatively high and, by contrast, contrives to create income in periods when business performance is unfavourable and income is comparatively low (Donelson, Ross \& John, 2011).

In Saman, Mohammed and Omid (2012), income smoothening expectations depend on three main assumptions, which the first is that the manager derives a non-monetary private advantage from running the firm. Another assumption is deprived performance leads to interference by the firm which later resulting in a decrease of the manager's private advantage. Third, recent income annotations are weighted more than prior annotations in assessing the manager's recent performance. In contrast, other studies assess income smoothening as an instrument for executives to disclose their private information about forthcoming earnings (Johnson, Thomas \& Juan, 2011). Such statement could be either active or passive. For instance, Khajavi, Ghorbaniand \& Maharlouie (2011) showed that reported earnings have dual roles. The level of reported earnings allows investors to conclude the level of stable future cash flows. The variations of reported earnings decrease the investors' confidence in the concluded stable component. The dual roles cause executives to smooth earnings.

Using signaling framework, Moradi (2008) claimed that only firms with decent future prospects smoothen earnings since borrowing from the future could be catastrophic to a poorly performing firm once the problem explodes in the near term. Private information about forthcoming earnings can similarly be communicated passively. Al-Qaisi (2011) exhibited that executives smoothen income to dress consumption besides that in so doing they disclose private information about future earnings. Chen (2008) revealed that, even in the nonattendance of an incentive, forthcoming earnings are partly communicated in effective contracting as long as managers use future earnings information to decide whether they smoothen current earnings. Whether information is communicated actively or passively, income smoothing might make firms' current and past earnings further informative about forthcoming earnings and cash flows.

According to Hussein et'al, (2013), there are two types of smoothening: real and artificial. Real smoothening comprises making production and speculation decisions that decrease income inconsistency. In dissimilarity, artificial smoothing is attained through accounting practices. Atwood and Hong (2011) performed a long-run empirical analysis between smoothening and stock profitability, using U.S. companies' stock information as their sample. They categorized the companies as smoothers and non-smoothers on the ground of the sales variation coefficient vs. the earnings variation coefficient. By means of geometric series of returns as a foundation for calculation, they revealed that the non-smoother sample had greater average income than the smoother sample. Nevertheless, the monthly average income used in their study was not adjusted for risk. There is also a variance in size and risk among the two samples: the smoothing group was larger and had a smaller beta than the nonsmoothening group, even though there was no statistical evidence to support this result.

Donelson, Ross and John (2011) studied the Finnish market to comprehend if abnormal return, as derived from earnings disclosures, was different among companies that do and do not demonstrate smoothing behaviour, based on the variation coefficient method. The results exhibited that smoothers inclined to be bigger than nonsmoothers, and the former also had smaller betas than their equivalents. When speaking of abnormal returns, the non-smoothers displayed better market performance against variability of income when linked to smoothers. More in recent times, Siti et'al., (2013) re-examined if the accounting performance measures are associated to income smoothing, but this time using abnormal returns. The results of this approach are based on the accumulation of abnormal returns by means of arithmetic series. The results exhibited that smoothers have a suggestively higher abnormal return than non-smoothers. The smoothers, according to the market value of liquid assets, were bigger than non-smoothers.

\subsubsection{Income Tax Yield}

Income tax yield refers to the income or earnings obtained from taxes by the relevant tax authorities. Income tax yield may manifest in twofold: firstly, a reduction in income taxes that results from taking allowable deductions from taxable income, and secondly an increase in income taxes that result from employing all tax machineries to the advantage of the relevant tax authorities (Frank \& Goyal, 2009). For example, since interest on debt is a taxdeductible expense, it usually creates a reduction in income taxes.

The place of taxation is primal in generating public revenue. Public goods and services are mostly funded from tax revenues in private sector driven economies thus governments all over the world places a premium on tax. In strong tax driven economies, default is considered as a financial crime against the state and treated as such. Also in these economies, the bulk of tax revenue accrues from earnings of corporations in all dimensions from the very big to the very small. This central role occupied by taxation as recognized in the extant literature has remained a major tool for economic policy planning of this private sector led economies. Thus, earnings from corporate 
bodies are critical to the level of yield from tax.

Siti, et'al. (2013) believed that creative accounting moderates year-to-year fluctuations in income tax yield by shifting tax earnings from peak years to less successful ones, making tax earnings fluctuations less volatile. Furthermore, the extant literature as espoused by Tokuga and Saki, (2011) documented the drivers of creative accounting to include; reducing tax payments, projecting a better managerial image, attracting investors, increasing stock price, lowering the cost of financing, reducing the risk premium of capital assets, and all of which increase a firm's value.

Furthermore, as noted by Graham and Allen (2006), income tax yield has been on the decline as a result of a reduction in taxable income for individuals and corporations through claiming allowable allowances (deductions) such as mortgage interest, medical expenses, charitable donations, amortization and depreciation. These deductions reduce taxpayers' taxable income for a given year or defer income taxes into future years.

\subsection{Theoretical Premise}

This study is premised on the utilitarianism theory which focuses on the dilemma in the business world. Fritzche and Becker (1984) believed that utilitarianism focuses on the notion of maximizing the ultimate amount of good (i.e. utility) for the ultimate number of individuals. Masten (2012) opined that the relationship of ethics is implied in the definition, where an act is considered ethical if most of the individuals are happy and receiving a benefit. The basis of utilitarianism according to Bentham (1843) can be attained in consequentialist backgrounds, where the ends finally justify the means. There are two varied forms of utilitarianism: first is the rule-utilitarianism (emphasis is on the maximization of happiness with respect to the actions to a particular rule and the second is actutilitarianism, which evaluates the probable rule and considers the greatest happiness that results from this action (Audi, 2007). The connection of this theory to accounting is that accountants are expected to utilize a particular rule (i.e. code of professional conduct) in order to maximize the happiness of shareholders such that their actions to a particular rule is in conformity with the code of professional conduct.

The rule-utilitarianism lays the foundation for professional accountants to follow the code of professional conduct of the profession in their execution of their accounting tasks. The rule-utilitarianism thus implies that when these code of professional conduct of the profession are duly followed, professional accountants will not engage themselves in actions that may be detrimental to the shareholders. Thus, the code of professional conduct which is the rule is there to guide the actions or behaviour of the professional accountant in the reporting system. According to Chonko (2012), there is the likelihood of conflicting rules in rule-utilitarianism. This however, give rise to accountants exploring these conflicting rules and utilizing them to the advantage of the organization and detrimental to the shareholders.

\subsection{Hypothesis Development}

Okoro and Okoye (2016) examined international financial reporting standards (IFRSs) as a way of taming creative accounting, as well as, factors that trigger unethical accounting practices in Nigeria. The paper utilized structured questionnaires administered to 120 professionals (auditors, investors, stockbrokers). The Pearson Product Moment Correlation statistical tool was used in analyzing the field data. Based on the analysis, they found that IFRSs can be used to tame creative accounting. This implies that IFRSs moderate excessive unethical accounting practices. In addition, the study found that one of the most significant factors triggering negative creative accounting is 'conflict of interest'.

The study by Fizza and Malik (2015) which scrutinizes creative accounting and financial reporting via structured questionnaires found that creative accounting negatively affects financial reporting. The negative influence is caused by the role played by corporate governance in financial reporting. They believed that creative accounting destroys the image of the company. Furthermore, Kiani and Malik (2015) explored creative accounting in a bid to differentiate earnings management and fraud. They showed that earnings management is done within the regulatory requirements, while fraud is done outside the regulatory requirements. Their findings showed that banks, auditors, investors, regulatory authorities, are involved in creative accounting. On his part, Amat (2013) investigated the nature and prevalence of creative accounting within the milieu of ethical considerations. The study showed that creative accounting is ethically questionable to the professional accountant. However, the ethical dilemma militating against the professional accountant encompasses conflict of interest, client proposals to maneuver financial statements and client proposals for tax evasion.

Another study by Nejad, Zeynali and Alavi (2013) on income smoothening in Tehran Stock Exchange using Index Eckel, supported the position that accounting is one of the methods corporate firms adopt in manipulating financial statements. In specific terms, the study investigated creative accounting on three levels of profits: net, gross and operating profits and accounting. The study by Fizza and Malik (2015) which scrutinizes creative accounting and financial reporting via structured questionnaires found that creative accounting negatively affects financial reporting. The negative influence is caused by the role played by corporate governance in financial reporting. They believed that creative accounting destroys the image of the company. 
Also Al-Qaisi (2011) showed that income smoothening increases the abnormal returns and market values of the companies. In Iran, Moradi (2008) showed that there is a negative significant relationship between financial leverage and income smoothing. Also, in companies that have a higher free cash flow, there is more negative significant relationship between financial leverage and income smoothing.

Based on the review of empirical literature, it is obvious that most studies on creative accounting were conducted outside Nigeria, thus this study was carried out to fill the gap inherent in the accounting literature on creative accounting construct. Arising from the foregoing the study interrogated how creative accounting practice impacts on corporate income tax yield?

\section{Ho1: Income tax yield is not significantly affected by creative accounting practices of Nigerian firms}

\section{Methodology}

Descriptive survey design was deployed in the current study which is in tandem with the submission of Nachmias and Nachmias (2009). Data for the current study was obtained from the South-South (an acronym for the six states located in the southernmost part of Nigeria) State Boards of Internal Revenue via a structured research questionnaire and personal interview. 270 questionnaires were distributed to the six states but 258 were successfully retrieved and used. The reliance on data collected from these six State Boards of Internal Revenue to conduct this current study was premised on the homogeneity of the operations of all thirty-six State Boards of Internal Revenue, irrespective of the nomenclature used in the different States.

The data collection instrument was pretested to eliminate all forms of ambiguity and to ensure validity and retested to ensure reliability. Also, the internal regularity of the instrument was determined using the Cronbach Alpha reliability test and a safety margin of 0.71 and 0.95 .5 on average were achieved. Furthermore, STATA 13.0 Microsoft windows software was deployed to analyze and synthesize the data with particular emphasis on descriptive (frequency counts, mean and standard deviation) and inferential (simple regression) statistical tools. The regression model is given as:

$$
\begin{aligned}
& I T Y=f(C A P)
\end{aligned}
$$

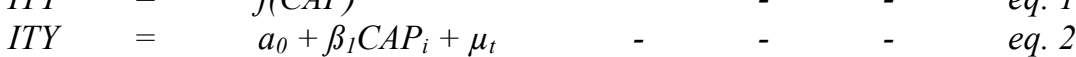

Where: ITY $=$ Income tax yield of Nigerian firms; CAP $=$ Creative accounting practices of Nigerian firms; $a_{0} \beta_{1}=$ regression equations and $\mu_{\mathrm{t}}=$ error term

\section{Data Analyses}

The data of the study are presented in tables 1-4 below:

Table 1: Demographic Variables of Respondents

\begin{tabular}{|c|c|c|c|c|}
\hline Ranks & Variables & Respondents & Frequency $\mathrm{N}=\mathbf{2 5 8}$ & Percent $(\%)$ \\
\hline \multirow[t]{3}{*}{1} & Gender & Male & 132 & $51.16 \%$ \\
\hline & & Female & 126 & $48.84 \%$ \\
\hline & & Total & 258 & $100.0 \%$ \\
\hline \multirow[t]{6}{*}{2} & Academic & SSCE & 11 & $4.26 \%$ \\
\hline & Qualification & $\mathrm{OND} / \mathrm{NCE}$ & 97 & $37.60 \%$ \\
\hline & & B.Sc./HND & 115 & $44.57 \%$ \\
\hline & & M.Sc./MBA & 30 & $11.63 \%$ \\
\hline & & $\mathrm{PhD}$ & 5 & $1.94 \%$ \\
\hline & & Total & 258 & $100.0 \%$ \\
\hline \multirow[t]{5}{*}{3} & Work & $1-5$ years & 48 & $18.60 \%$ \\
\hline & Experience & 6-10years & 120 & $46.51 \%$ \\
\hline & & 11-20years & 78 & $30.23 \%$ \\
\hline & & 21 years \& above & 12 & $4.65 \%$ \\
\hline & & Total & 258 & $100 \%$ \\
\hline \multirow[t]{9}{*}{4} & Position & Deputy Director Tax Consultant & 6 & $2.33 \%$ \\
\hline & & Chief Inspector Of Taxes & 12 & $4.65 \%$ \\
\hline & & Principal Inspector Of Taxes & 6 & $2.33 \%$ \\
\hline & & Senior Inspector Of Taxes & 42 & $16.28 \%$ \\
\hline & & Chief Principal Officers & 90 & $34.88 \%$ \\
\hline & & Assistant Chief Accountant & 6 & $2.33 \%$ \\
\hline & & Senior Accountant & 6 & $2.33 \%$ \\
\hline & & Accountant II & 13 & $5.04 \%$ \\
\hline & & Inspector Of Taxes & 6 & $2.33 \%$ \\
\hline
\end{tabular}




\author{
Administrative Officer \\ Executive Officer \\ Planning Officer \\ Tax Officer \\ Vehicle Licensing Officer \\ Info. \& Comm. Technologist \\ Personal Assistant \\ Others \\ Total
}

\title{
Source: Field Survey, 2019
}

Presented in Table 1 are the demographic variables of two hundred and fifty-eight (258) respondents who are employees of State Boards of Internal Revenue, South-South of Nigeria. The results revealed that 132(51.16\%) of the respondents are male while 126(48.84\%) are female. On the academic qualification, 11(4.26\%) and $97(37.60 \%)$ are SSCE and OND/NCE holders while $115(44.57 \%)$ and $30(11.63 \%)$ are B.Sc./HND and M.Sc./MBA degree holders respectively. Only 5(1.94\%) are PhD holders. The study data shows that $48(18.60 \%)$ and $120(46.51 \%)$ are within the age brackets of 1-5years and 6-10years while $78(30.23 \%)$ and $12(4.65 \%)$ are within the age brackets of 11-20years and 21years and above respectively.

Furthermore, it was found that majority of the respondents sampled were more of Chief Principal Officers of the State Boards of Internal Revenue, Bayelsa State of Nigeria representing 90(334.88\%) and Senior Inspector of Taxes representing 42(16.28\%). The vast majority of the above respondents sampled are indication of the fact that these sets of respondents should possess more knowledge on the research subject.

Table 2: Descriptive Statistics showing Responses on Creative Accounting (CAP) among Creative Accounting Practice by Nigerian Firms

\begin{tabular}{|clcc|} 
S/N & \multicolumn{1}{c}{ Items } & Mean & $\begin{array}{l}\text { Std. } \\
\text { Dev. }\end{array}$ \\
\hline 1 & As personal income tax liability is not appealing to individuals, so it is to firms & 3.9535 & 1.2775 \\
\hline 2 & $\begin{array}{l}\text { From our observation, most Nigerian firms are involved in creative accounting } \\
\text { practice }\end{array}$ & 3.6744 & 0.8291 \\
\hline 3 & $\begin{array}{l}\text { Creative accounting can be done within the regulatory provisions, which prompts } \\
\text { firms' involvement. }\end{array}$ & 4.0233 & 0.5062 \\
\hline 4 & $\begin{array}{l}\text { Often times, creative accounting practices of firms' exceed the acceptable legal } \\
\text { threshold. }\end{array}$ & 3.4884 & 0.8192 \\
\hline 5 & $\begin{array}{l}\text { Organizations engage in creative accounting in order to reduce income tax liability } \\
\text { 6raudulent financial manipulations are often contrived under the disguise of creative }\end{array}$ & 4.0000 & 0.9902 \\
\hline $\begin{array}{l}\text { accounting? } \\
\text { Income smoothening has become a regular practice of Nigerian firms }\end{array}$ & 3.6279 & 1.0591 \\
\hline 8. & $\begin{array}{l}\text { The inability to immediately detect the number game often lures managers of firms } \\
\text { to continue from minor manipulations to very major ones until they are caught }\end{array}$ & 4.8140 & 0.9962 \\
\hline 9 & $\begin{array}{l}\text { Often, the lack of technical expertise amongst regulatory agencies to quickly detect } \\
\text { and isolate incidence cases encourages firms to cook the books beyond the acceptable } \\
\text { legal limits. } \\
\text { GRAND MEAN/STD. DEV. }\end{array}$ & 3.8837 & 0.8253 \\
\hline
\end{tabular}

Source: Field Survey, 2019

Table 2 presents the questions on creative accounting practice (CAP) among the Nigerian firms. The result showed that all the nine (9) items on creative accounting scored above 2.50 cut-off point of the mean. This suggests that the nine (9) items are good indicators in assessing creative accounting and are fundamental to income tax yield. On the overall, the grand mean of 3.8450 which is above the cut-off point of mean is an indication that the firms consider creative accounting as a major practice. 
Table 3: Descriptive Statistics showing Responses on Income Tax Yield (ITY) among Employees of States Boards of Internal Revenue, South-South of Nigeria: Income Tax Yield

\begin{tabular}{|rlcc|}
\hline S/N & \multicolumn{1}{c}{ Items } & Mean & Std. Dev. \\
\hline 1 & Income tax yield is dependent on reported accounting numbers & 3.7442 & 0.8120 \\
\hline 2 & Given an option, no firm likes to pay appropriate tax & 4.1861 & 0.8712 \\
\hline 3 & Firms have a general propensity towards minimized tax liability & 4.0465 & 0.6817 \\
\hline 4 & Firms often explore and exploit every loophole within existing tax laws & 4.2558 & 0.7197 \\
\hline 5 & $\begin{array}{l}\text { Reliance on finished and published accounting numbers to determine tax income } \\
\text { is affecting the yield from tax }\end{array}$ & 3.9302 & 0.8475 \\
\hline 6 & $\begin{array}{l}\text { Available tax laws creates opportunities for corporate firms to minimize their tax } \\
\text { obligations }\end{array}$ & 3.9302 & 0.6623 \\
\hline 7 & $\begin{array}{l}\text { Our agency is not equipped with the requisite technical and personnel support to } \\
\text { maximize returns from tax }\end{array}$ & 3.0233 & 1.1931 \\
\hline 8. & $\begin{array}{l}\text { The over dependence on crude oil for public revenue led to a weakened tax } \\
\text { administrative structure with implications for optimal tax yield }\end{array}$ & 4.3488 & 0.7449 \\
\hline 9. & $\begin{array}{l}\text { Weak enforcement and penal instruments undermine our efforts at optimizing } \\
\text { income tax yield }\end{array}$ & 4.3721 & 0.6491 \\
\hline 10. & $\begin{array}{l}\text { Firms are always exploiting available loopholes within the tax laws to the } \\
\text { detriment of the system }\end{array}$ & 4.1163 & 1.0849 \\
\hline 11. & $\begin{array}{l}\text { Exceeding the regulatory threshold of cooking the figures have greatly marred } \\
\text { the yield from tax revenue }\end{array}$ & 3.6774 & 0.60492 \\
\hline 12 & $\begin{array}{l}\text { Increased dependence on tax revenue as a primary source of public revenue } \\
\text { generation would enhance the existing tax structure and optimize greater returns. } \\
\text { GRAND MEAN/STD. DEV. }\end{array}$ & 4.4186 & 0.6049 \\
$\mathbf{4 . 0 0 4 1}$ & $\mathbf{0 . 7 8 9 7}$ \\
\hline
\end{tabular}

\section{Source: Field Survey, 2019}

Table 3 presents the questions on income tax yield (ITY) among the employees of State Boards of Internal Revenue, South-South of Nigeria. The result showed that all the twelve (12) items on income tax yield scored above 2.50 cut-off point of the mean. This implies that the twelve (12) items are good indicators in assessing income tax yield and are fundamental to explaining creative accounting. Absolutely, the grand mean of 4.0041 which is above the cut-off point of mean shows that the employees of the six States' Boards of Internal Revenue consider income tax yield to be connected with creative accounting.

Ho1: Income tax yield is not significantly affected by creative accounting practices of Nigerian firms Table 4: Regression Results for Creative Accounting (CAP) and Income Tax Yield (ITY)

\begin{tabular}{|c|c|c|c|c|c|}
\hline Source & SS & $d f$ & MS & Number of obs $=$ & 258 \\
\hline & & & & $F(1,256)=$ & $=4620.77$ \\
\hline Model & 127.645503 & 1 & 127.645503 & Prob $>F$ & $=0.0000$ \\
\hline Residual & 7.07181946 & 256 & .027624295 & R-squared & $=0.9475$ \\
\hline & & & & Adj $\mathrm{R}$-squared = & 0.9473 \\
\hline Total & 134.717323 & 257 & .524191918 & Root MSE & .16621 \\
\hline
\end{tabular}

\begin{tabular}{r|rrrrrr}
\hline ity & Coef. & Std. Err. & $t$ & P $>|t|$ & {$[95 \%$ Conf. Interval] } \\
\hline $\operatorname{cap}$ & .8103291 & $\begin{array}{c}.0119208 \\
\text { (omitted) }\end{array}$ & 67.98 & 0.000 & .7868538 & .8338043 \\
\hline cans & .8959424 & .0469884 & 19.07 & 0.000 & .8034094 & .9884753 \\
\hline
\end{tabular}

Source: Field Survey, 2019 
Presented in Table 4 is the regression result for creative accounting (CAP) and income tax yield (ITY). The $\mathrm{R}$-squared for CAP is 0.9475 , indicating that the independent variable explains about $94.75 \%$ of the systematic variations in ITY. The f-ratio indicates that creative accounting $(\mathrm{CAP}=4620.77 \mathrm{Prob}<\mathrm{f}=0.0000)$ significantly affects income tax yield. In addition, the p-value of CAP (0.0000) implies that there is significant relationship between creative accounting practices and income tax yield among Nigerian firms. Hence, the null hypothesis was rejected and alternate hypothesis was accepted that income tax yield is significantly affected by creative accounting practices of Nigerian firms.

\section{Conclusion and Recommendations}

Quite a number of studies have shown that creative accounting practices significantly affect the profitability of firms; however, there is dearth of empirical evidence on whether income tax yield is significantly affected by creative accounting practices of Nigerian firms. Hence, this study was carried out to investigate the nexus between creative accounting practices and income tax yield in Nigeria. The perceptions of employees of States' Boards of Internal Revenue in the South-South Geopolitical Zone of Nigeria were obtained and their views analyzed using both descriptive and inferential statistical tools. On the basis of the findings, it was found that income tax yield is significantly affected by creative accounting practices of Nigerian firms.

Based on the analysis of data, it was recommended that the government, regulatory framework of accounting and management of firms should further discourage the use of creative accounting mechanisms in fine-tuning income tax yield, given the fact that creative accounting destroys firms' reputation/image. More importantly, the regulatory framework of accounting should as a matter of fact postulate and revise accounting standards connected with income tax yield so as to further discourage creative accounting practices among Nigerian firms.

\section{References}

Adebimpe, O. U. (2009). Accounting disclosures and corporate attributes in Nigeria listed companies. Unpublished PhD thesis submitted to the Department of Accounting, College of Business and Social Sciences, Covenant University, Ota, Ogun State, Nigeria.

Ahmed, A. \& Scott, D. (2011). Evidence on the role of accounting conservatism in monitoring managers' investment decisions. Accounting and Finance, 51(3),609.

Al-Qaisi, M.K., (2011). Income smoothening practicing effect on abnormal returns and market value. International Research Journal of Finance and Economics 79, 120-127.

Amat, O. (2013). Creative accounting: Nature, incidence and ethical issues. Journal of Economic Literature, 1(1), $1-19$.

Atwood, T.J., \& Hong, X. (2011). The market mispricing of special items and accruals: One anomaly or two? Review of Accounting and Finance, 9 (2), 156.

Chen, U.R. (2008). Corporate governance and cash holdings: Listed new economy versus old economy firms. Corporate Governance 16(5), 430-442.

Davoud, P. \& Bita, M. (2008). Analyzing relationship between financial ratios and Stock return for income Smoothing and non-smoothing companies, separately. Quarterly of Financial Researches, 24, 81-98

Donelson, D., Ross, J. \& John, M. (2011). Changes over time in the revenue-expense relation: Accounting or Economics? The Accounting Review, 86 (3), 945-975.

Fakhari, H. \& Taghavi, S.R. (2010). Accruals quality and corporate cash holdings. The Iranian Accounting and Auditing Review, 16, 69-84.

Fizza, T. \& Malik, Q.A. (2015). Creative accounting and financial reporting: Model development and empirical testing. International Journal of Economics and Financial Issues, 5(2), 544-551

Frank, M. Z. \& Goyal, V. K. (2009) Corporate borrowing and tax shield: Which factors are reliably important? Financial Management, 38, 1-37.

Graham, J. R. \& Allen, T. (2006) Tax shelters and corporate debt policy. Journal of Finance forthcoming.

Hossein, S.N. Sina, Z. \& Seyed, S.A. (2013). Investigation of income smoothing at the Companies listed on the stock exchange by the using Index ECKEL: Case study of Tehran Stock Exchange. Asian Journal of Management Sciences and Education, 2(2), 1-14

Johnson, P., Thomas, L. \& Juan, S. (2011). Special items: A descriptive analysis, Accounting Horizons, 25 (3), 511-536.

Khajavi, S.H., Ghorbani, A. \& Maharlouie, M.M. (2011). Survey of efficiency of modern and traditional liquidity indexes in forecasting income smoothing of companies. Iranian Journal of Accounting Knowledge 2(4), 105124.

Moradi, M. (2008). Evaluation of relationship between financial leverage and income smoothing in the Tehran Stock Exchange. Iranian Financial Research 9(3), 99-124.

Nachmias F. \& Nachimias, D. (2009). Research Methods in the Social Science, (5th edition). United Kingdom: Hodder Educational Books 
Okoro, G.E. \& Okoye, E.I. (2016). Taming creative accounting via International Financial Reporting Standards: The Nigerian scenario. Business Trends, 6(4), 11-17

Popoola, C. F., Akinsanya, K., Babarinde, S. B., \& Farinde, D. A. (2014). Published financial statement as a correlate of investment decision among commercial bank stakeholders in Nigeria. International Journal of Social, Management, Economics and Business Engineering 8(1).

Riedl, E., \& Suraj, S. (2010). Signaling firm performance through financial statement presentation: Items. Contemporary Accounting Research, 27 (1),289

Saman, M., Mohammed, M.M. \& Omid, M. (2012). The effect of cash holdings on income smoothing. Interdisciplinary Journal of Contemporary Research in Business, 4(2), 523-532

Siti, M., Haron, S. \& Henny M.M.T. (2013). Income smoothing and Islam: An evidence from Malaysian Sharia Compliant Companies. International Journal of Social Science and Humanity, 3(2),160-162

Staubus, G.J. (1952). Payments for the use of capital and the matching process. The Accounting Review, 27(1),104113.

Tokuga, Y. \& Saki, A. (2011). Income smoothing as a form of accounting policy by managers: A case study of Onward Kashiyama. Working Paper, 1-25

Uma, V. \& Gregory, K (2012). Big bath, income smoothing, and special items: an empirical investigation. Public and Municipal Finance, 1(1), 80-86

\section{APPENDIX 2a}
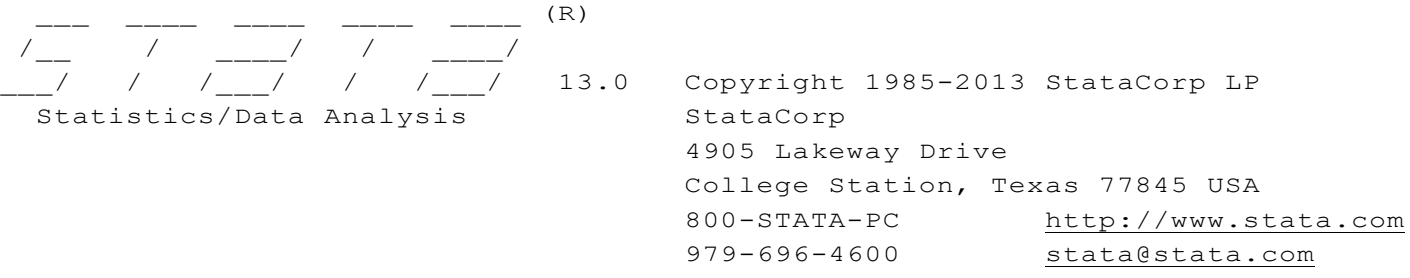

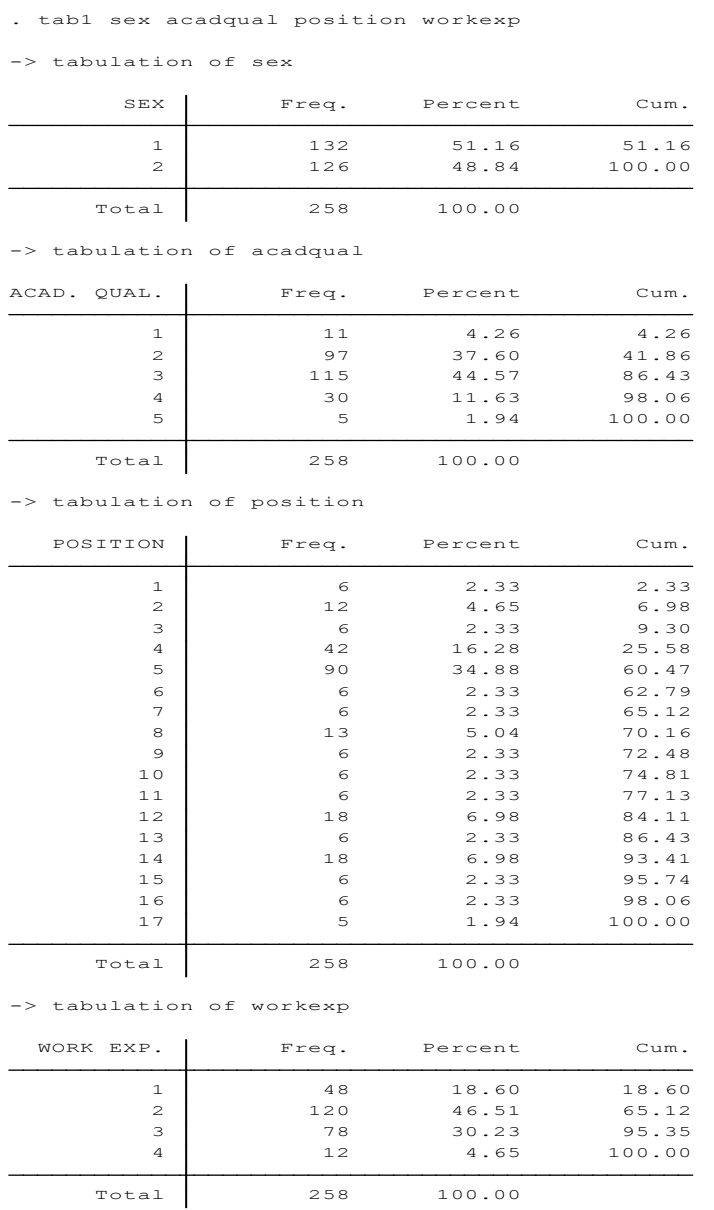




\section{APPENDIX 2b}

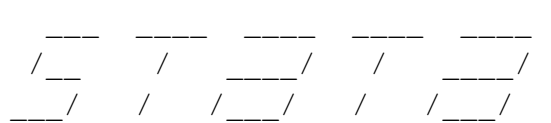

Statistics/Data Analysis
(R)

13.0

Copyright 1985-2013 stataCorp LP

StataCorp

4905 Lakeway Drive

College station, Texas 77845 USA

$\begin{array}{ll}\text { 800-STATA-PC } & \text { http://www.stata.com } \\ \text { 979-696-4600 } & \text { statadstata.com }\end{array}$

979-696-4601 (fax)

- summarize q1 q2 q3 q4 q5 q6 q7 q8 q9 q10 q11 q12 q13 q14 q15 q16 q17 q18 q19 q20 q21

\begin{tabular}{|c|c|c|c|c|c|}
\hline Variable & Obs & Mean & Std. Dev. & Min & $\operatorname{Max}$ \\
\hline q1 & 258 & 3.953488 & 1.277525 & 1 & 5 \\
\hline q2 & 258 & 3.674419 & .8290709 & 1 & 5 \\
\hline q3 & 258 & 4.023256 & .5062276 & 3 & 5 \\
\hline q4 & 258 & 3.488372 & .8191889 & 1 & 5 \\
\hline q5 & 258 & 4 & .9902246 & 1 & 5 \\
\hline$q 6$ & 258 & 3.627907 & 1.059107 & 1 & 5 \\
\hline q7 & 258 & 3.813953 & .9962376 & 1 & 5 \\
\hline q8 & 258 & 4.139535 & .8251323 & 2 & 5 \\
\hline q9 & 258 & 3.883721 & .995147 & 1 & 5 \\
\hline$q 10$ & 258 & 3.744186 & .8111966 & 2 & 5 \\
\hline q11 & 258 & 4.186047 & .8712212 & 1 & 5 \\
\hline q12 & 258 & 4.046512 & .6817289 & 3 & 5 \\
\hline q13 & 258 & 4.255814 & .7196959 & 2 & 5 \\
\hline q14 & 258 & 3.930233 & .8478496 & 2 & 5 \\
\hline q15 & 258 & 3.930233 & .6623393 & 2 & 5 \\
\hline q16 & 258 & 3.023256 & 1.193139 & 1 & 5 \\
\hline q17 & 258 & 4.348837 & .744904 & 2 & 5 \\
\hline q18 & 258 & 4.372093 & .6490912 & 3 & 5 \\
\hline q19 & 258 & 4.116279 & 1.084937 & 2 & 5 \\
\hline q20 & 258 & 3.767442 & .6049295 & 3 & 5 \\
\hline q21 & 258 & 4.418605 & .6912198 & 2 & 5 \\
\hline
\end{tabular}




\section{APPENDIX 2c}

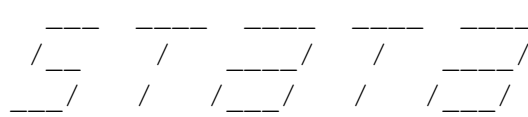

Statistics/Data Analysis
13.0 Copyright 1985-2013 stataCorp LP

StataCorp

4905 Lakeway Drive

College Station, Texas 77845 USA

800-STATA-PC http://www.stata.com

979-696-4600 statalstata.com

$979-696-4601$ (fax)

- regress ity cap cap

note: cap omitted because of collinearity

\begin{tabular}{r|crr} 
Source & SS & df & MS \\
\hline \begin{tabular}{r|rl} 
Model \\
Residual
\end{tabular} & $\begin{array}{r}127.645503 \\
\text { T.07181946 }\end{array}$ & 256 & .027624295 \\
\hline Total & 134.717323 & 257 & .524191918
\end{tabular}

Number of obs $=\quad 258$

$F(1,256)=4620.77$

Prob $>\mathrm{F}=0.0000$

$\mathrm{R}$-squared $\quad=0.9475$

Adj $\mathrm{R}$-squared $=0.9473$

Root MSE $=.16621$

\begin{tabular}{|c|c|c|c|c|c|c|}
\hline ity & Coef. & Std. Err. & t & $P>|t|$ & [95\% Conf. & Interval] \\
\hline cap & .8103291 & .0119208 & 67.98 & 0.000 & .7868538 & .8338043 \\
\hline cap & 0 & (omitted) & & & & \\
\hline _cons & .8959424 & .0469884 & 19.07 & 0.000 & .8034094 & .9884753 \\
\hline
\end{tabular}

